\title{
Enhancing Employee's Creative Performance by Providing Training among Employees of Small and Medium-sized Enterprises (SMEs) in Malaysia
}

\author{
Md Murad Miah \\ Dr Nor Intan Adha Hafit \\ MSc in Business Management \\ Faculty of Business and Management \\ UniversitiTeknologi MARA (UiTM) \\ 40450 Shah Alam, Selangor, Malaysia
}

\begin{abstract}
Small and Medium-sized of Enterprise (SMEs) are one of the fundamental pillars of the sustainable economic growth of Malaysia. Surprisingly, various research has shown that there is an issue arising in the sector of SMEs where scholars concern about low innovation in the SMEs of Malaysia. Additionally, one of the sides of low innovations shows by SMEs due to the lack of creative and trained employees. On the other hand, there is a limited research focus on the relationship between employee training and creative performance in the sector of SMEs in Malaysia. Hence, this research is going to focusing on enhancing employee creative performance by providing training among employees of SMEs in Malaysia. However, after review of the recent works of the literature shows that suitable training can enhance employee knowledge and skills that required employees domain and creativity relevant skills and when employees feel that organization investing in their skills and knowledge development its help them to engage with the organization alongside improving task motivation. Furthermore, this research is not out of limitation, firstly; objectives have not tested yet and focus on for-profit organization, therefore, the researcher suggests further research should focus on examining the relationship between training and employee creative performance. Last not but least, the researcher also suggests for further research need to focus on the nonprofit organization where can identify different perspective between training and employee creative performance.
\end{abstract}

Keywords: Employee Creative Performance, Training, Small and Medium-sized Enterprises (SMEs), Malaysia.

\section{Introduction}

In response to the present globalized knowledge-based economy organizations have to hook the amount of technological and demographical strengths to persevere and be productive in this challenging and energetic work environment (Lopes, Scavarda, Hofmeister, Thomé, and Vaccaro, 2017). Appropriately, the organization ought to concentrate on creativity and innovation which can make competitive advantage and maintainable development among its adversaries (Kremer, Villamor, and Aguinis, 2019). Besides, in today's competitive scene, an organization ought to stay one step ahead to win the belief and certainty of customers (Lopes et al, 2017).Subsequently, to bargain with the customers' demand, the organization ought to concoct come up with creative issues understanding and inventive solutions for the complex challenges within the work environment (Liao and Tsai, 2019). Besides, at the authoritative level, creativity originates from workers who are the basic and nontangible assets of the organization.

This is often since, one of the essential objectives of the HR division to boost representative inventiveness by giving appropriate training (Veth, Korzilius, Van der Heijden, Emans, and De Lange, 2019).) which builds up staff's creativity relevant skills within the challenging work environment (Lee, Pak, Kim, and Li, 2019).

From the Malaysian point of view, there are a lot of creativity issues rising within the range of small and mediumsized of the enterprise (Hanifah, Halim, Ahmad, and Vafaei-Zadeh, 2019; Halim, Ahmad, and Ramayah, 2019). Various research likewise has illustrated that due to the non-creative workers within the small and medium size of enterprise the tremendous majority of the organizations are raised sustainability issues amid the opening of early age. (Hanifah et al., 2019; Halim et al., 2019; Abdullah, Ping, Wahab, and Shamsuddin, 2014, September). The Ministry of International Trade Industry (2018) realizes that due to the non-creative employees and need of trained employees this kind of issue confronted by small and medium-sized of enterprise in Malaysia. Hence, this thinks about will be attending to concentrate on upgrading employee creative execution by providing training within the little and medium-sized of enterprise in Malaysia. 


\section{Small and Medium-sized Enterprises (SMEs) and Employee Creativity}

The enhancement of SMEs of endeavours structures one of the fundamental ways of Malaysian initiatives to gain sustainable economic growth and to see developed nation status persistently 2020 (Abdul-Mohsin, 2020; Abdullah et al., 2014). Regardless, to achieve postulations initiatives, creativity and innovation may expect a basic work as drivers for growth and intensity (Hanifah et al., 2019). SMEs are the most suppliers and service providers to the industries, in this way, they require innovative and handy workers to concentrate on their objective especially when they are major employers within the labour advertise. As appeared by CompareHero (Sept 25, 2019) as of now within the segment of SMEs give 5.7 million occupations to $70 \%$ of Malaysia's workforce. Thus, the insights appear that SEMs are made a bigger number of jobs than large ventures and are inalienably work heightened.

Other than the commitment to giving a job, there's an issue emerging in front of SMEs which is concerning low innovation (Abdullah et al., 2014; Hanifah et al., 2019). National study of the report (2015) illustrated that 64.25\% of small organizations are less creative dependent on justify. Moreover, as demonstrated by the Ministry of International Trade and Industry (2018) found that a nonappearance of innovation and adaptability of SMEs since of the nonattendance of exceptionally much-prepared employees. Various research moreover recognized that over $40 \%$ of SMEs are not providing training to their staff (Abdullah et al., 2014; Khalique, Isa, Nassir Shaari, and Ageel, 2011). Consequently, it impacts on non-creative culture among employees within the SMEs. In any case, research recognizes that the knowledge and aptitudes gotten from the training are appeared to improve worker creativity (Afolayan, Olukayode, Sulaiman, and Owolabi, 2019; Chaubey and Sahoo, 2019: Liu, Gong, Zhou, and Huang, 2017).

\section{Theoretical Framework}

\section{Training and Employee Creative Performance}

Training is a program that is to make strides the specialized aptitudes, knowledge, adequacy, and esteem creation to do a specific job in an enormously progressed manner. Also, training grows the specified aptitudes set and associates within the improvement of inventive thoughts, basic considering capacities within the perplexing working environment (Blomberg, 1989). As demonstrated by (Afolayan et al., 2019) training can update workers' knowledge and capacities which are essential for innovative thoughts and grant such opportunities that move forward creativity relevant skills (Chaubey and Sahoo, 2019). By offering training opportunities that can construct employees' knowledge base or their creativity relevant skills, employees will endeavour to be continuously innovative in their work (Athwaria, 2016).In the below adding latest studies that show the relationship between training and employee creativity;

\begin{tabular}{|c|c|c|}
\hline Authors & Title & Findings \\
\hline $\begin{array}{l}\text { Afolayan, M. } \\
\text { A., Olukayode, } \\
\text { A., Sulaiman, A. } \\
\text { T., \& Owolabi, } \\
\text { L. T. (2019). }\end{array}$ & $\begin{array}{l}\text { Training and Employee Creative Performance: } \\
\text { A Study of Chevron Nigeria. }\end{array}$ & $\begin{array}{l}\text { The result shows that training plays positive } \\
\text { relationships with employee creative performance }\end{array}$ \\
\hline $\begin{array}{l}\text { Chaubey, A., \& } \\
\text { Sahoo, C. K. } \\
(2019) \text {. }\end{array}$ & $\begin{array}{l}\text { Role of HR interventions in enhancing } \\
\text { employee creativity and } \\
\text { innovation: an empirical study. }\end{array}$ & $\begin{array}{l}\text { The finding shows that training has a positive } \\
\text { relationship with employee creativity. }\end{array}$ \\
\hline $\begin{array}{l}\text { Liu, D., Gong, } \\
\text { Y., Zhou, J., \& } \\
\text { Huang, J. C. } \\
(2017) .\end{array}$ & $\begin{array}{l}\text { Human resource systems, employee creativity, } \\
\text { and firm innovation: The moderating role of } \\
\text { firm ownership. }\end{array}$ & $\begin{array}{l}\text { The result found that extensive training plays } \\
\text { significant positive relationships with employee } \\
\text { creative. }\end{array}$ \\
\hline $\begin{array}{l}\text { Jaiswal, D., \& } \\
\text { Dhar, R. L. } \\
(2017) .\end{array}$ & $\begin{array}{l}\text { Impact of human resources practices on } \\
\text { employee creativity in the hotel industry: The } \\
\text { impact of job autonomy. }\end{array}$ & $\begin{array}{l}\text { The result identified that HRM practices havea positive } \\
\text { relationship with employee creativity. }\end{array}$ \\
\hline $\begin{array}{l}\text { Yadav, A. } \\
(2016)\end{array}$ & $\begin{array}{l}\text { Linking Potential Training Outcomes to } \\
\text { Employee Creativity in Retailing: A Systems } \\
\text { View. }\end{array}$ & $\begin{array}{l}\text { The result represents that training outcomes play a } \\
\text { positive relationship with employee creativity. }\end{array}$ \\
\hline $\begin{array}{l}\text { Athwaria, S. } \\
(2016) \text {. }\end{array}$ & $\begin{array}{l}\text { High-Performance Work Practices 'and } \\
\text { Employees 'Creativity: Testing the relationship } \\
\text { ‘. }\end{array}$ & $\begin{array}{l}\text { The findings show training has a positive relationship } \\
\text { with employee creativity. }\end{array}$ \\
\hline $\begin{array}{l}\text { Chang, S., Jia, } \\
\text { L., Takeuchi, R., } \\
\& \text { Cai, Y. } \\
(2014) .\end{array}$ & $\begin{array}{l}\text { Do high-commitment work systems affect } \\
\text { creativity? A multilevel combinational } \\
\text { approach to employee creativity. }\end{array}$ & $\begin{array}{l}\text { The result shows that HCWS positively related to } \\
\text { employee creativity. Additionally, one of the variables } \\
\text { of HCWS is training. }\end{array}$ \\
\hline $\begin{array}{l}\text { Nawaz, M. S., } \\
\text { Hassan, M., } \\
\text { Hassan, S., } \\
\text { Shaukat, S., \& } \\
\text { Asadullah, M. }\end{array}$ & $\begin{array}{l}\text { Impact of employee training and empowerment } \\
\text { on employee creativity through employee } \\
\text { engagement: Empirical evidence from the } \\
\text { manufacturing sector of Pakistan. }\end{array}$ & $\begin{array}{l}\text { The result of the study shown that the impact of } \\
\text { employee training has a positive relationship with } \\
\text { employee creativity. }\end{array}$ \\
\hline
\end{tabular}


A. (2014).

Abdullah, N. H., Perception of training and employee The result shows that training has a positive

Ping, L. L.,

innovativeness: An evidence from small firms. relationship between employee innovativeness.

Wahab, E., \&

Shamsuddin, A.

(2014,

September).

Jiang, J., Wang,

S., \& Zhao, S.

Does HRM facilitate employee creativity and organizational innovation? A study of Chinese firms.

The researcher was using five HRM practices; one of them is training.

(2012).

The result has shown that there is a negative relationship with employee creativity.

Based on the literature reviewed the theoretical framework shown in figure 1 is proposed:

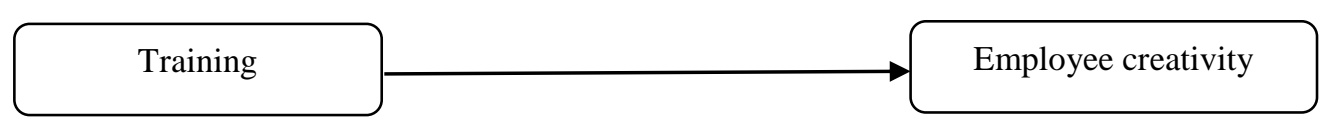

Figure 1: Proposed theoretical framework for predicting relationship between training and employee creativity.

From the above study shows that there is a positive relationship between training and employee creativity. Therefore, we are developing hypothesis;

H1: There is a relationship between training and employee creative performance.

\section{Componential Theory of Creativity}

Componential theory of creativity is the principal persuasive theory of creativity which is proposing by Amabile (1988). The theory is representing that individual creativity has three sections: domain-relevant skills, creativity relevant processes and task motivation. As a matter of first importance, domain-relevant skills part alludes to the knowledge and skills in a particular domain. Other than that, Creativity-relevant processes discussing express or inferred knowledge about reasonable procedures for delivering innovative thoughts, suitable strategies styles, and work style. Task motivation is the third piece of the componential theory of creativity, which alludes to the perspectives of individuals towards an errand and their perspective on their motivation (Amabile, 1988).

For explicit, training fundamentally extends workers' assortment of domain-relevant skills and skill basic for being innovative (Amabile, 1983). Training practices can be custom fitted to overhaul the two areas of the domainrelevant skills and creativity relevant skills. Besides, innovativeness can overhaul employee knowledge and aptitudes that are fundamental to develop inventive thought structures and provide opportunities that update task domain skills (Liu et al., 2019;:Lau and Ngo, 2004). Then again, training can create staff competency and aptitudes, in this manner, it causes employees to feel that organizations are contributing to building up their competency and improvement. Hence, it normally inspired employees to focus on the job (Mostafa,Gould- Williams, and Bottomley, 2015).

From the above contentions, it shows that suitable training practices cause employees to gain domain-relevant skills and creativity relevant skills alongside task motivation. Consequently, the componential theory of creativity is a standout amongst other fit theory to help the connection between training and employee creativity.

\section{Conclusion}

This study has shown that there is a positive relationship between training and employee creative performance. This study also found that when employees get training, they can develop their skills and competency which helps on domain-relevant skills and creativity relevant skills and improve task motivation. Other than that, this research focuses on small and medium size of enterprise where the researcher tries to come out of the real situation on the crisis of employee creativity. 
Moreover, the main contribution of this study which added a theoretical framework on the relationship between training and employee creative performance. Secondly, this research focuses on SMEs labour market where the majority of the workforce working in the Malaysian industry, but shockingly, the research found that lack of creativity arises by the employees of SMEs. The practical contribution of this study will be the guideline for the SMEs to provide the training of employees and upgrade their skills and competency which is required for creative performance.

Furthermore, this study is not out of limitation; first, the objectives of the study have not tested yet. Thus, further research should focus on training or other HR practices to employee creativity but need to test the objectives.Thus, this study focusses on SMEs or for-profit organization, therefore, the researcher suggests conducting the nonprofit organization like; higher education where can get the various perspective of employee creativity.

\section{References}

Abdul-Mohsin, A. (2020). The relationship between entrepreneurial competencies, competitive intelligence, and innovative performance among SMEs from an emerging country: competitive intelligence in SMEs. In Start-Ups and SMEs: Concepts, Methodologies, Tools, and Applications (pp. 884-906). IGI Global.

Afolayan, M. A., Olukayode, A., Sulaiman, A. T., \& Owolabi, L. T. (2019). Training and employee creative performance: a study of chevron Nigeria. Training and employee creative performance: a study of chevron Nigeria, 4l(1), 6-6.

Athwaria, S. (2016). High-Performance Work Practices 'and Employees 'Creativity: Testing the relationship '. International Journal of Human Resource \& Industrial Research, 3(3), 79-92.

Abdullah, N. H., Ping, L. L., Wahab, E., \& Shamsuddin, A. (2014, September). Perception of training and employee innovativeness: An evidence from small firms. In 2014 IEEE International Conference on Management of Innovation and Technology (pp. 76-80). IEEE.

Amabile, T. M. (1988). A model of creativity and innovation in organizations. Research in organizational behaviour, 10(1), 123-167.

Amabile, T. M. (1983). The social psychology of creativity: A componential conceptualization. Journal of personality and social psychology, 45(2), 357.

Blomberg, R. (1989). Cost-benefit analysis of employee training: A literature review. Adult Education Quarterly, 39(2), 89-98.

CompareHero (September 25, 2019): SME Landscape of Malaysia. Retrieved from:

https://www.comparehero.my/sme/articles/sme-landscape-malaysia

Chaubey, A., \& Sahoo, C. K. (2019). Enhancing organizational innovation in the Indian automobile industry. International Journal of Innovation Science.

Chang, S., Jia, L., Takeuchi, R., \& Cai, Y. (2014). Do high-commitment work systems affect creativity? A multilevel combinational approach to employee creativity. Journal of Applied Psychology, 99(4), 665.

Halim, H. A., Ahmad, N. H., \&Ramayah, T. (2019). Sustaining the Innovation Culture in SMEs: The Importance of Organizational Culture, Organizational Learning and Market Orientation. Asian Journal of Business Research, 9(2), 14.

Hanifah, H., Halim, H. A., Ahmad, N. H., \&Vafaei-Zadeh, A. (2019). Emanating the key factors of innovation performance: leveraging on the innovation culture among SMEs in Malaysia. Journal of Asia Business Studies.

Jaiswal, D., \& Dhar, R. L. (2017). Impact of human resources practices on employee creativity in the hotel industry: The impact of job autonomy. Journal of Human Resources in Hospitality \& Tourism, 16(1), 1-21.

Jiang, J., Wang, S., \& Zhao, S. (2012). Does HRM facilitate employee creativity and organizational innovation? A study of Chinese firms. The International Journal of Human Resource Management, 23(19), 4025-4047.

Kremer, H., Villamor, I., \&Aguinis, H. (2019). Innovation leadership: Best-practice recommendations for promoting employee creativity, voice, and knowledge sharing. Business Horizons, 62(1), 65-74.

Khalique, M., Isa, A. H. B. M., Nassir Shaari, J. A., \&Ageel, A. (2011). Challenges faced by small and medium enterprises (SMEs) in Malaysia: An intellectual capital perspective. International Journal of Current Research, 3(6), 398.

Lopes, C. M., Scavarda, A., Hofmeister, L. F., Thomé, A. M. T., \& Vaccaro, G. L. R. (2017). An analysis of the interplay between organizational sustainability, knowledge management, and open innovation. Journal of Cleaner Production, 142, 476-488.

Liao, Y. C., \& Tsai, K. H. (2019). Innovation intensity, creativity enhancement, and eco- innovation strategy: The roles of customer demand and environmental regulation. Business Strategy and the Environment, 28(2), 316-326.

Lee, H. W., Pak, J., Kim, S., \& Li, L. Z. (2019). Effects of human resource management systems on employee proactivity and group innovation. Journal of Management, 45(2), 819-846. 
Liu, D., Gong, Y., Zhou, J., \& Huang, J. C. (2017). Human resource systems, employee creativity, and firm innovation: The moderating role of firm ownership. Academy of Management Journal, 60(3), 1164-1188.

Lau, C. M., \& Ngo, H. Y. (2004). The HR system, organizational culture, and product innovation. International business review, 13(6), 685-703.

Ministry of International Trade and Industry (2018). Malaysia International Trade and Industry Report 2018. Retrieved from: https://www.miti.gov.my/index.php/pages/view/1771.

Mostafa, A. M. S., Gould- Williams, J. S., \& Bottomley, P. (2015). High- performance human resource practices and employee outcomes: the mediating role of public service motivation. Public Administration Review, 75(5), 747-757.

Nawaz, M. S., Hassan, M., Hassan, S., Shaukat, S., \& Asadullah, M. A. (2014). Impact of employee training and empowerment on employee creativity through employee engagement: Empirical evidence from the manufacturing sector of Pakistan. Middle East Journal of Scientific Research, 19(4), 593-601.

National survey of Innovation (2015). Retrieved from: https://mastic.mestecc.gov.my/sti-survey-contentspds/national-survey-innovation-2015.

Veth, K. N., Korzilius, H. P., Van der Heijden, B. I., Emans, B. J., \& De Lange, A. H. (2019). Which HRM practices enhance employee outcomes at work across the life-span?. The international journal of human resource management, 30(19), 2777-2808.

Yadav, A. (2016). Linking Potential Training Outcomes to Employee Creativity in Retailing: A Systems View. Amity Journal of Training and Development, 1(1), 32-35. 